\title{
Controversial aspects of diapause development
}

\author{
Ivo HODEK
}

Institute of Entomology, Academy of Sciences, Branišovská 31, 37005 Č. Budějovice, Czech Republic; e-mail: hodek@entu.cas.cz

Key words. Diapause development, diapause intensity, post-diapause quiescence, horotelic processes, tachytelic processes, synchronization, vigour

\begin{abstract}
Although some parts of diapause development have been clarified up by endocrinologists, knowledge of the underlying processes remains insufficient. The survey of ecophysiological aspects of diapause development has thus to be limited to inputs and outputs from the blackbox. The terms diapause development, diapause intensity, post-diapause quiescence, horotelic processes of diapause, and tachytelic processes of diapause (reactivation) are defined. Andrewartha's term diapause development has been accepted because it shows diapause as a dynamic event.

In about the last 20 years, some views on diapause development have been updated, while others have fossilised. The assumption that chilling is a general prerequisite for completion of diapause development in all insects still survives in part of the scientific community, in spite of much contradictory evidence and often due to inadequate interpretation of experiments (examples given in figures and tables). On the contrary, it has been generally recognised that in temperate climates overwintering diapause is usually already completed in early/mid winter and the dormancy is then temperature quiescence. The conception of multiple pathways of diapause completion postulates that diapause can be completed either by the normal (slow) progress of diapause development (horotelic processes), or by a faster activation (tachytelic processes). There are important differences between the mechanisms regulating activation and the horotelic processes. Thus, e.g., the photoperiodic response is lost during horotelic completion, while after photoperiodic activation it persists. In addition to photoperiodic activation other kinds of activation are being studied, particularly activation by high temperature.

Some conclusions can be made from modern studies on diapause development. In every individual, several (at least two) possible pathways exist that are evidently interlinked and mutually complementary. Thus the time of diapause passed at any condition has to be considered, as well as the exposure to very low temperatures. In temperature studies the experimental range ought to be adequately wide and less affected by a priori assumptions. Stimulation by temperature increase or improvement in food or other conditions has to be considered.

The success of diapause completion should be measured by at least four parameters: (1) incidence (\%) of developmental steps; (2) duration of delay; (3) synchronization; (4) vigour of post-diapause insects (shown by long-term survival or fecundity). The last two parameters have usually been neglected.
\end{abstract}

\section{INTRODUCTION}

Diapause vs. quiescence. Fifty years ago, our thinking about diapause was changed in a major way: We began to view diapause as a dynamic phenomenon (a process that has to be completed), thanks to the classical review of Andrewartha (1952), where the concept of diapause development was introduced and explained as physiogenesis (physiological developmental processes), in contrast to the "normal" morphological development, morphogenesis. The half-century distance should be a good occasion to reflect how much Andrewartha's paradigm has been assimilated or perhaps developed by extensive studies. Instead of repeating the information already published in a short history of ecophysiological diapause studies (Hodek, 1999), the focus here will be on several problematic aspects of diapause development. Also I avoid quoting definitions of diapause because they may be easily found in compendia and review articles (Denlinger, 1985; Tauber et al., 1986; Danks, 1987; Hodek, 1996). However, two aspects should be stressed that have often been a source of misunderstanding.

(1) During diapause, morphogenesis is arrested, but growth, mobility or feeding often are not discontinued. One recent example that diapause is not a stand-still of growth was recorded during the larval diapause of a drosophilid fly, Chymomyza costata (Kostal et al., 2000): both the central nervous system and prothoracic wing discs increased in size during diapause. In diapause larvae of the corn-stalk borer, Sesamia nonagrioides, nonstationary supernumerary molts were reported (Gadenne et al., 1997). Low levels of juvenile hormone allow the previtellogenic growth of ovaries in diapause females of the carabid beetle Pterostichus angustatus (Holters, 1981). Vitellogenesis, however, is blocked until diapause completion.

(2) Another important characteristic of diapause, mentioned in all definitions, is its indirect dependence on environmental cues: while quiescence is caused by direct inhibition of development by conditions below or above developmental thresholds, diapause is a particular adaptive developmental arrest that is induced by so called "token stimuli". These environmental cues act as signals, but they do not directly prevent the morphogenesis. Understanding this difference between diapause and quiescence is essential for discussion of the controversial period of post-diapause, when development is directly prevented by the absence of some essential requirements. 


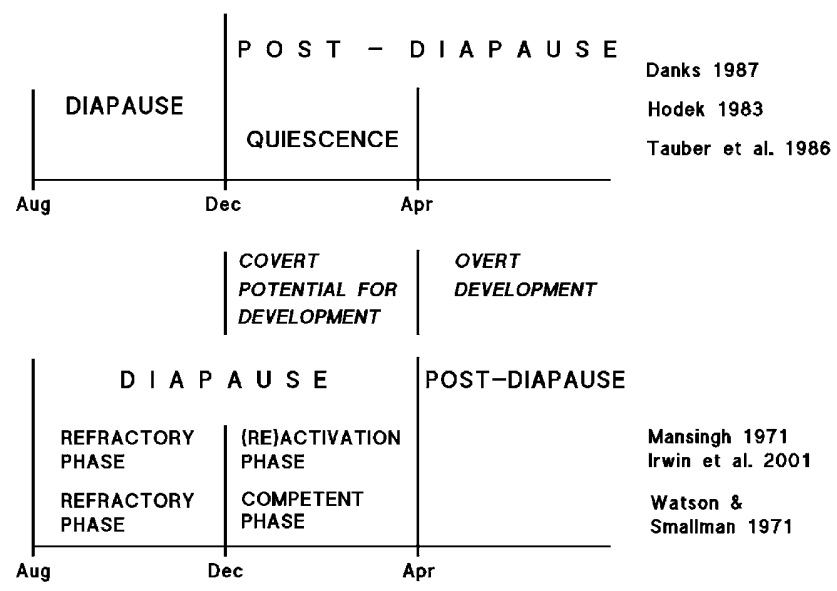

Fig. 1. Two conceptions of diapause and post-diapause shown for winter diapause in cold temperate climate.

Diapause development. There is plenty of evidence from ecophysiological experiments that the intensity of diapause gradually decreases through the period between diapause onset and diapause end. This process of decrease in diapause intensity, that was called diapause development and defined as physiogenesis by Andrewartha (1952), results finally in diapause completion. However, we still do not know what is the essence of the processes of diapause development.

The cascade of events/processes between these two points has been identified only partly. By physiological studies on neuroendocrine organs earlier outputs can be recorded, i.e. events that are situated some steps upstream of the changes in target organs. Already in the $1950 \mathrm{~s}$ and 1960 s, detailed studies on pupal diapause in Hyalophora cecropia and Manduca sexta (see, e.g., Wilson \& Larsen, 1974 , also for references to earlier studies) gave solid evidence that in the course of diapause development the brain resumes competence to stimulate by its hormones downstream organs (first endocrine glands). But the nature of the resumption of competence has remained an enigma. On the other hand, the resulting effect at the level of endocrine glands is relatively well understood (Denlinger, 1985; Hodkova, 1999). In several instances the progress of diapause development was shown by changes in responsiveness to exogenously added hormones. Thus, e.g., higher doses of juvenile hormone were needed for ovarian maturation in Leptinotarsa decemlineata at the beginning of diapause than in later stages of diapause development (Schooneveld et al., 1977). The increase in metabolic rate has often been reported as an indication of diapause completion. The steep increase in daily increment of respiration rate from 0.0054 to $0.1379 \mu 1 \mathrm{CO}_{2} / 24$ $\mathrm{h}$ (measured at $25^{\circ} \mathrm{C}$ ) strongly suggests completion of diapause approximately after $95 \mathrm{~d}$ in the eggs of Lymantria dispar kept at $5^{\circ} \mathrm{C}$ and 16L : 8D (Gray et al., 1995). However, usually the possibility has not been excluded that this increase is a symptom of starting morphogenesis, rather than of late diapause-development processes. In diapause adults of Ips acuminatus, kept at low temperature of $10^{\circ} \mathrm{C}$ and in darkness, a significant increase in oxygen consumption in mid-overwintering could indicate the completion of diapause (Gehrken, 1985); although also in this instance $10^{\circ} \mathrm{C}$ appears to be above the developmental threshold. As Footitt and Cohn (2001) rightly warned it is essential to avoid confusing diapausecompleting processes with post-diapause events. Recently, interesting biochemical changes were recorded in the pupal diapause of the flesh fly, Sarcophaga crassipalpis (Rinehart et al., 2001). The protein ultraspiracle (the dimerization partner of the ecdyson receptor) is not detectable in days 20-40 of diapause while it reappears in late diapause in day 50.

In spite of the great progress in physiological and biochemical studies our knowledge of the concrete nature of diapause development remains very limited. Thus I will review the studies recording the effect of environmental factors as inputs to a black box and the evidence of morphogenesis as outputs from it.

Post-diapause. Before starting the review, what is understood under the period of diapause has to be made clear. There exist two concepts of diapause (Fig. 1). According to the concept used in this review, diapause is over when the p o t e $\mathrm{n} t \mathrm{i}$ a 1 for development (morphogenesis) is resumed. This potential cannot be realized if the environmental conditions are not favourable for morphogenesis: in such a state, defined as quiescence (Lees, 1955), morphogenesis is d i r e c t 1 y inhibited by low ambient temperature, dryness, absence of essential food, etc. For the contrasting approach, the whole time of inactivity of endocrine glands is diapause, which also includes the period when morphogenesis is inhibited directly (Fig. 1 , below). Although this controversy may seem only terminological, it can produce important misinterpretation of findings and wrong decisions in pest management. Gillott (1995, p. 549) maintains that diapause of the Colorado potato beetle is terminated as late as by the increase in soil temperature. He thus contradicts the conclusions of long-term studies by de Wilde's school.

Some authors realised that the long diapause they were studying is not homogeneous and called the 2nd part the "activation phase" (Mansingh, 1971) or more adequately the "competent phase" (Watson \& Smallman, 1971); the first part is the refractory phase in both papers (Fig. 1). To prevent misunderstanding, the reader of a given paper should definitely be informed which of the above two concepts of diapause has been used.

The term diapause development has not been accepted by all authors because of semantic controversy. Critics find the construction illogical and, formally, they are right: it speaks, in fact, about development of an arrest of development. Some examples of terms that were proposed to replace diapause development are listed by Danks (1987, in Table 2). However, most recent authors (but see "diapause ending processes" in Wipking, 1995) do not seem to be irritated by the semantic problems and are using the term, because of its great advantage - it stresses the dynamic aspect of diapause. This is why it will also be used here. 


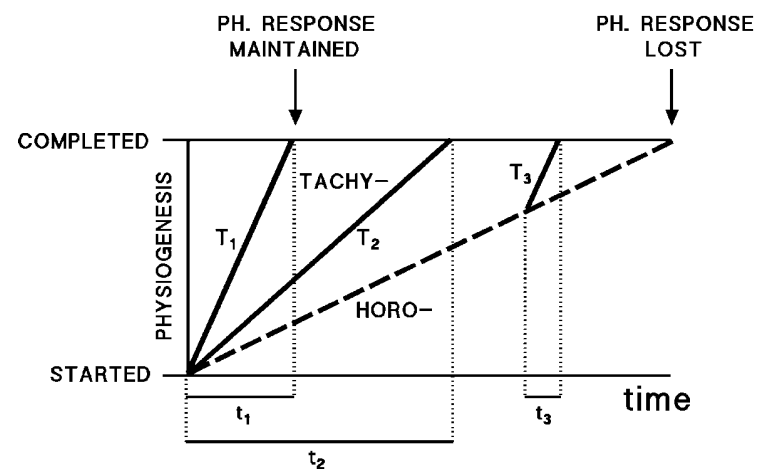

Tachytelic processes (activation) can be more $\left(T_{1}\right)$ or

less $\left(T_{2}\right)$ intensive and diapause completion is thus achieved in shorter $\left(t_{1}\right)$ or longer $\left(t_{2}\right)$ time. If the horotelic processes (diapause development) are more advanced the completion is attained faster $\left(t_{3} c f . t_{1}\right)$ by tachytelic processes of the same intensity $\left(\mathrm{T}_{3}\right)$.

Fig. 2. Interrelation between horotelic and tachytelic processes of diapause completion (from Hodek, 1983).

\section{HOROTELIC / TACHYTELIC PROCESSES OF DIAPAUSE DEVELOPMENT}

The accumulated experimental evidence has gradually made clear that the resumption of morphogenesis can be achieved by at least two types of processes of diapause development (Fig. 2). By Andrewartha's (1952) diapause development, diapause is completed in a rather slow way - in the order of months. Abundant experiments with photoperiodic activation have shown that the completion of diapause can be strongly accelerated - so that morphogenesis is resumed within only weeks. However, the resumption may be achieved also by high temperatures (as is discussed on this page, below).

Photoperiodic activation (tachytely). The first, pioneer findings on photoperiodic activation in mosquitoes by Baker date from 1935. In the 1960 s and later, numerous studies of photoperiodic activation followed (for examples see Tauber et al., 1986; Danks, 1987, Tables $21 \& 22$ ). The wealth of information continued to grow, but the later studies did not modify the concepts given there. The experimental evidence on diapause development and activation has been interpreted in various ways. Danilevsky $(1961$, p. 14) rejected the term diapause development because he felt that the term development was inappropriate for the resumption of a previous condition, and proposed the term cold reactivation instead. He maintained that in a majority of species diapause is neutral to light conditions (Danilevsky, 1961, p.18) - and, in fact he was right, as far as termination of winter diapause in $\mathrm{n}$ a t $\mathrm{ur}$ a $\mathrm{l}$ conditions is concerned. Later he accepted the term photoperiodic activation, and analysed this mechanism in Carpocapsa (Laspeyresia) pomonella (Danilevsky \& Sheldeshova, 1968). Both Vinogradova and Zaslavsky also used the term reactivation instead of diapause development (see below).

While the term photoperiodic (re)activation is adequate for the described mechanism and has since been generally used, the term cold reactivation has gradually been abandoned in papers published in English, evidently due to the
TABle 1. Species in which diapause is completed in midwinter (or analogous time for summer or tropical diapause).

Egg diapause

Lepidocyrtus lignorum Leinaas \& Bleken, 1983

Chortoicetes terminifera Hunter \& Gregg, 1984

Caledia captiva Groeters, 1994

Aulocara elliotti

Fisher et al. 1996; Fisher, 1997

Tortrix viridana

Du Merle, 1999

Deois flavopicta*

Pires et al., 2000

Larval diapause

$\begin{array}{ll}\text { Choristoneura fumiferana } & \text { Regniere, 1990 } \\ \text { Curculio elephas } & \text { Menu, 1993 } \\ \text { Allomyrina dichotoma } & \text { Yamanaka \& Fujiyama, 1994 } \\ \text { Sesamia nonagrioides } & \text { Lopez et al., 1995 } \\ \text { Kytorhinus sharpianus } & \text { Ishihara \& Shimada, 1996 } \\ \text { Strophingia ericae } & \text { Miles et al., 1998 }\end{array}$

Pupal diapause

Adult diapause

Asellus aquaticus (Crustacea) Tadini-Vitagliano et al., 1982

Culex tarsalis $\quad$ Reisen et al., 1995

Tetranychus kanzawai Mochizuki \& Takafuji, 1996

Cacopsylla pyricola Horton et al., 1998

Aulacophora nigripennis Watanabe \& Tanaka, 1998

*dry/cool season dormancy in a tropical insect (Di: IV-VII, post-Di quiescence:VII-X)

repeated findings that in the course of overwintering diapause the endogenous inhibition s p o $\mathrm{nt}$ a $\mathrm{n}$ e o u s $1 \mathrm{y}$ disappears as early as in mid-winter (Table 1). This discrepancy led the Russian authors to use a more adequate term - cold sensibilisation (Zaslavsky, 1988).

Horotely vs. tachytely. In spite of using different terms Zaslavsky (1988) and Hodek (1981, p. 323, 1983) shared very similar views on the processes during diapause. They both stressed that the "slow" and "fast" diapause processes are principally different, but interlocked, and are mutually complementary or additive (Fig. 2). The processes progressing at usually lower rate are named horotelic (= evolving at standard rate - Simpson, 1944, 1953; Henderson et al., 1953), while the accelerated processes are tachytelic ( $=$ evolving at a rate faster than the standard rate) (Hodek, 1983). Zaslavsky (1988) used the terms spontaneous vs. inductive processes.

The effects of horotelic and tachytelic completion of diapause differ in an important way. While Pyrrhocoris apterus adults remain sensitive to photoperiod and discontinue egg laying at short days early after the photoperiodic activation (Fig. 3A), the horotelic completion of diapause results in a loss of photoperiodic response, i.e. egg laying is maintained at short days (Fig. 3B) (Hodkova \& Hodek, 1989).

High temperature tachytely. The tachytelic completion of diapause may be achieved in some species or populations simply by high temperature, without photoperiodic activation. The earliest finding on termination of 


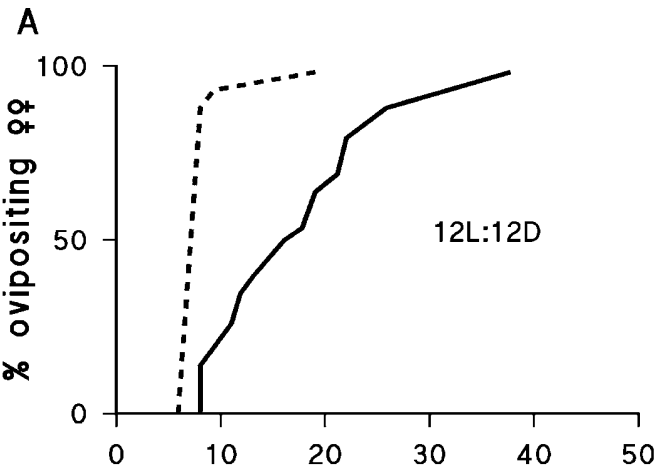

B

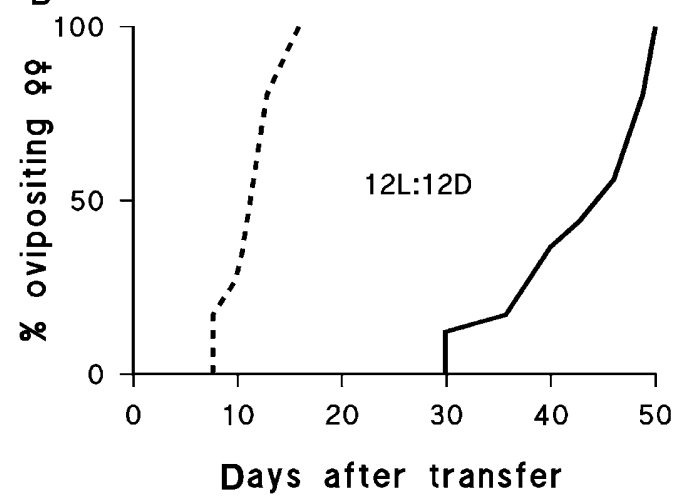

Fig. 3. Photoperiodic response after tachytelic completion of diapause at $26^{\circ} \mathrm{C}$ and $18 \mathrm{~L}: 6 \mathrm{D}(\mathrm{A})$ and horotelic completion of diapause at $15^{\circ} \mathrm{C}$ and $12 \mathrm{~L}: 12 \mathrm{D}(\mathrm{B})$. Dotted line indicates cummulative onset of oviposition; full line indicates cummulative cessation of oviposition (from Hodkova \& Hodek, 1989).
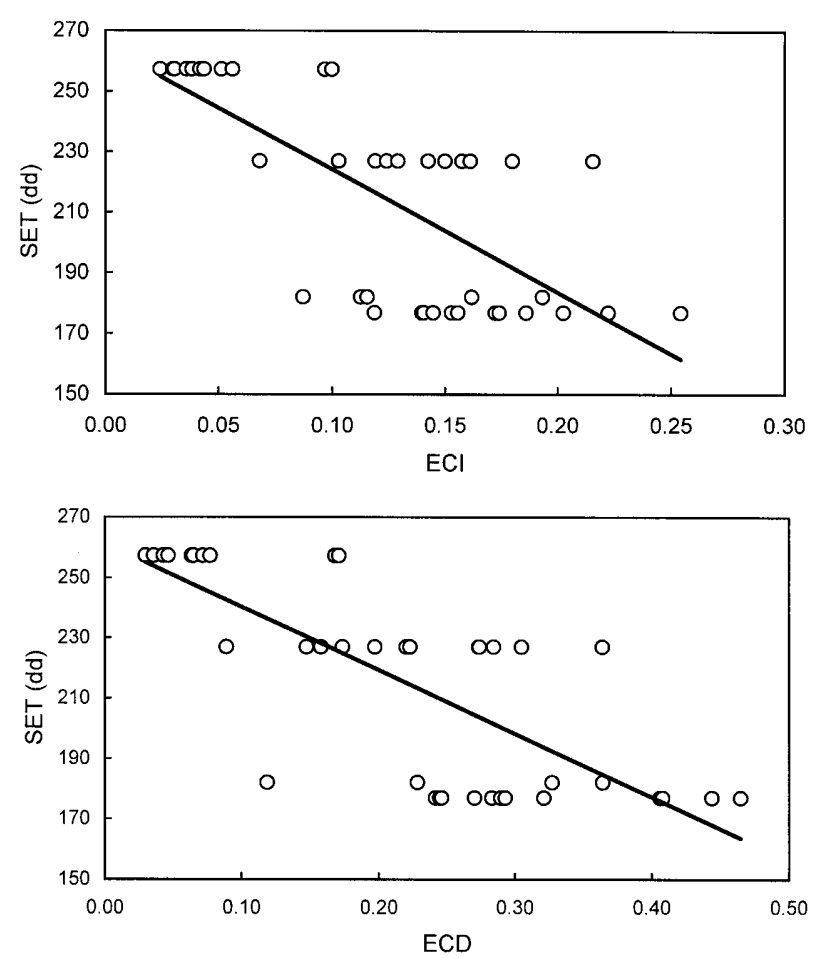

Fig. 4. Experimental treatments of diapausing eggs of Teleogryllus commodus (from Masaki et al., 1979).

diapause by high temperatures was probably that on eggs of a cricket, Teleogryllus commodus, by Browning (1952 a, b), Hogan (1960) and Masaki (1960). Later, Masaki et al. (1979) analysed this phenomenon in detail (Fig. 4).

TABLE 2. Species in which cool temperatures are a prerequisite for diapause development or shorten it (only rarely checked at an adequately wide range of temperatures; also it cannot be excluded that a temperature increase at transfer to incubation conditions participated in the effect of exposure to cool temperatures).

Egg diapause

Eurytoma plotnikovi

Locusta migratoria

Rhopalosiphum padi

Aulocara elliotti

Tortrix viridana

Larval diapause

Kytorhinus sharpianus

Trichogramma minutum

Monochamus alternatus

Psacothea hilaris

Colpoclypeus florus

Lagria hirta

Pupal diapause

Psila rosae

Coloradia pandora

Adult diapause

Argopistes biplagiatus

Dybowskyia reticulata

Thrips setosus

Gerris gracilicornis

\section{4 or $18^{\circ}$}

$15^{\circ}$ better than $5^{\circ}$ vs 20 or $25^{\circ}$

$-5^{\circ}$ vs $3^{\circ}$

$0-18^{\circ}$ (opt. $7-8^{\circ}$ ) vs $30^{\circ}$

only $8^{\circ}$

$5-10^{\circ}$

$$
\begin{gathered}
15+2^{\circ} \text { vs } 15^{\circ} \\
10^{\circ} \text { vs } 25^{\circ} \\
10^{\circ} \text { vs } 25^{\circ} \\
0,4,10^{\circ}
\end{gathered}
$$

perfect range $5-30^{\circ}$

$$
0,5,7^{\circ}
$$

only $5^{\circ}$

5 or $10^{\circ} ; 15^{\circ}$ too high

$10^{\circ}$ vs $25^{\circ}$

only $5^{\circ} ; 18^{\circ}$ too high

$7^{\circ}$ vs $20^{\circ}$
Tzanakakis et al., 1992

Tanaka, 1994

Lushai et al., 1996

Fisher, 1997

Du Merle, 1999

Ishihara \& Shimada, 1995

(but questioned by I \& S, 1996)

Laing \& Corrigan, 1995

Togashi, 1995

Shintani \& Ishikawa, 1997a, b

Milonas \& Savopoulu, 2000

Zhou \& Topp, 2000

Collier et al., 1994

Gerson et al., 1999

Inoue, 1994

Nakamura \& Numata, 1997

Nakao, 1998

Harada \& Taniguchi, 2001 

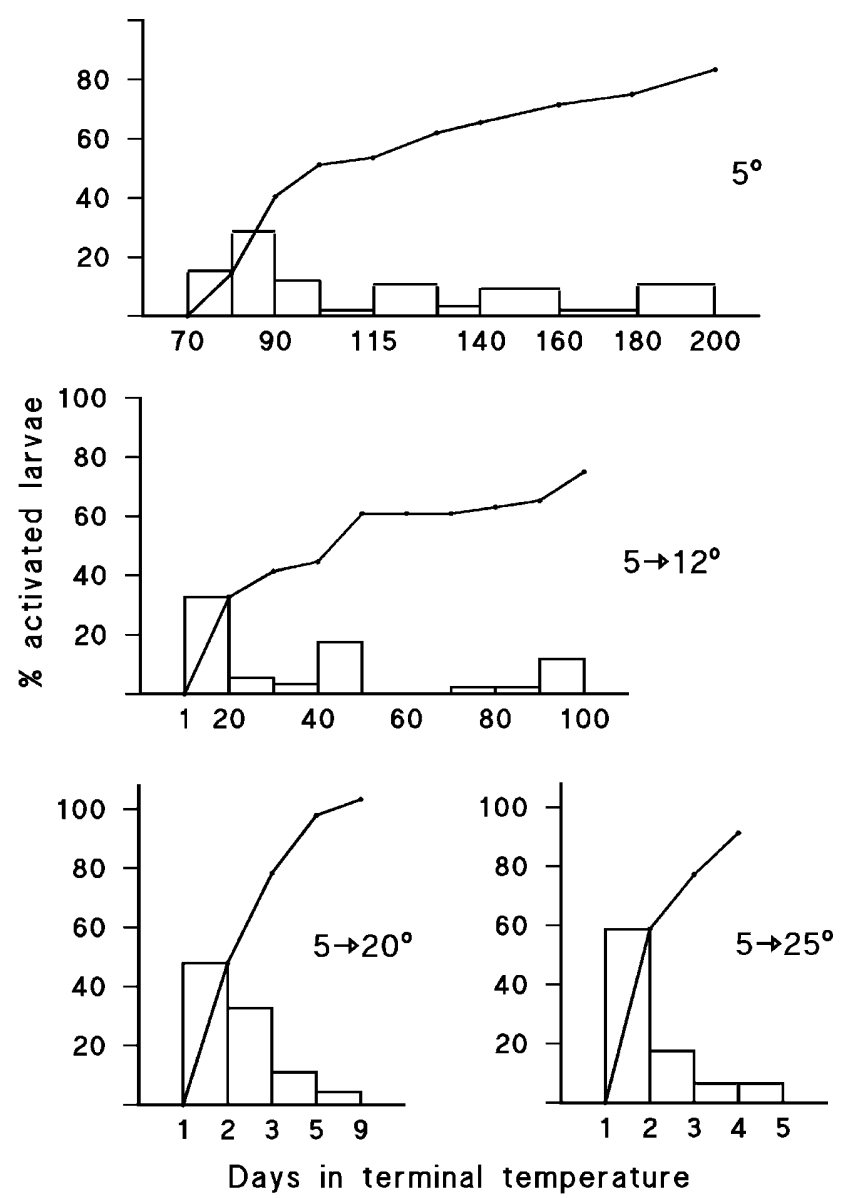

Fig. 5. Experimental treatments of diapause larvae of Calliphora vicina (from Vinogradova, 1991).

They concluded that (1) the eggs require high temperatures for a rapid termination of "the late stage" of diapause; and (2) low temperatures are not a requisite for the completion of diapause, although they are favourable for "the early stage" of diapause. An alternative interpretation might suppose that the upper figure shows the horotelic diapause development, in the middle figure a period of 60 days of horotelic diapause development at $20^{\circ} \mathrm{C}$ is followed by tachytelic activation at $30^{\circ} \mathrm{C}$, and, in the lower figure, the increase in temperature by $10^{\circ}$ to $20^{\circ} \mathrm{C}$, again after the 60 days of horotelic diapause development at $10^{\circ} \mathrm{C}$, represents the needed activation. It seems that in both cases tachytelic processes are started by the same $10^{\circ}$ increase. This study is an example showing how the horo- and tachytelic processes are additive.

The discrimination between horotelic (spontaneous) and tachytelic (inductive) processes of diapause development is easy when characteristic cases are considered. Typical diapause-averting photoperiods produce distinct tachytelic processes. Similarly, a high temperature (or an important temperature increase) results in explicit tachytely, as may be indicated by the above results on $T$. commodus (Masaki et al., 1979). Less distinct levels of cues, such as photoperiods near the critical threshold or intermediate temperatures, produce complex responses, and often a mixture of responses is recorded. The mixed response to the critical photoperiod follows from its definition. The response achieved in diapause larvae of Calliphora vicina exposed to $12^{\circ} \mathrm{C}$ is an example for the effect of intermediate temperature (Vinogradova \& Bogdanova, 1984; Vinogradova, 1991, pp. 84-90) (Fig. 5). At the age of 40 days, diapause larvae from the region of Tomsk were transferred from the temperature of $5^{\circ} \mathrm{C}$ to higher temperatures of 12 or 20 or $25^{\circ} \mathrm{C}$ under the diapausepromoting photoperiod, or were kept at $5^{\circ} \mathrm{C}$ as control. Pupariation of the larvae indicated termination of diapause. About $80 \%$ of control larvae completed their diapause development within 200 days, clearly due to horotelic processes. Developmental threshold in C. vicina is below $5^{\circ} \mathrm{C}$; thus the larvae could pupariate also at this low temperature. When the activating temperatures were 20 or $25^{\circ} \mathrm{C}$ the interval to pupariation was much shortened to 9 and 5 days, respectively. At these two high temperatures, tachytelic processes evidently completed diapause. However, in the case of transfer from 5 to 12 ${ }^{\circ} \mathrm{C}$, when the pupariation delay was 100 days, the multimodal distribution of pupariation indicates that probably less than $40 \%$ of larvae responded in the tachytelic way. The last mode of 70-100 days fits fully into the range of the horotelic diapause development.

Horotely in the field. For the adult winter diapause of spring breeders most authors have accepted that diapause is completed in the field (by horotely) after 4 to 5 months after induction, and changes then into quiescence, during which morphogenesis is hindered just by low ambient temperatures (Table 1). According to this generally accepted view, and in contrast to laboratory experiments on photoperiodic activation of winter diapause, and also in contrast to estivation diapause, there is usually no cue or stimulus terminating diapause, although the course of diapause development may be modified by some factors, such as temperature more or less close to the optimum for horotelic processes.

Is diapause measured by timer(s)? The duration of diapause is programmed genetically, but also by the conditions in the course of diapause induction (Danks, 1987; Kalushkov et al., 2001). The duration of diapause development (and survival) may be different under different temperatures; however, there is a certain minimum duration of this period, called "refractory" by Watson \& Smallman (1971). In the staphylinid Oxytelus rugosus, diapause development lasts 4 to 5 months and is completed without chilling (Topp, 1984, 1994). Topp speaks about a "specific time interval" needed and calls this feature "intrinsic" diapause. This concept resembles the rather old views expressed by Precht $(1963,1964)$ and Tischler (1963) in their papers on diapause of the lygaeid bug Ischnodemus sabuleti. They supposed that the duration of diapause is governed by a biological clock,"biologische Langzeituhren". In fact, we still cannot exclude the possibility that a timer measures the diapause, at least until we find some biochemical or molecular biological processes representing diapause development. Kai et al. $(1995,1999)$ reported that an enzyme served as interval 


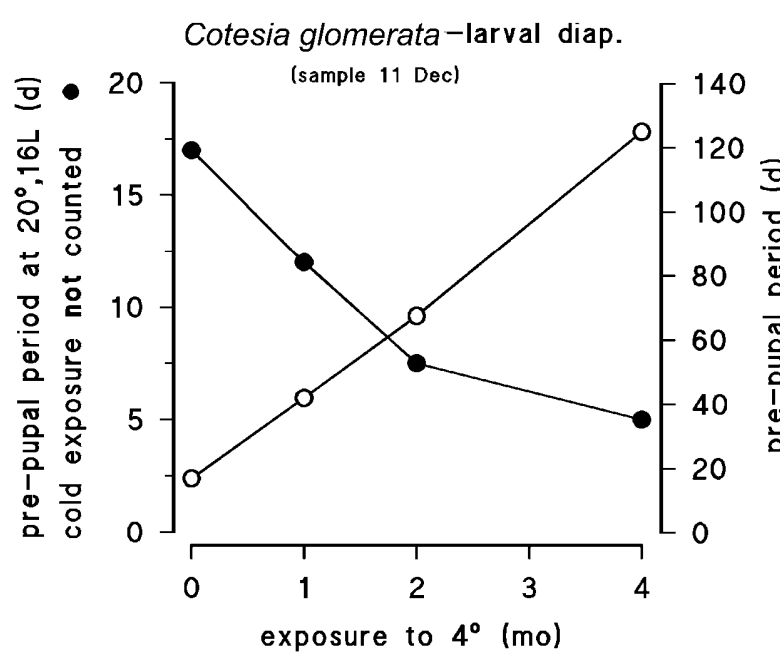

Fig. 6. The effect of cold exposure at $4{ }^{\circ} \mathrm{C}$ (compared to the exposure at constant $20^{\circ} \mathrm{C}$ ) on larval diapause in Cotesia glomerata with and without the "chilling" period (data from Ishii et al., 2000)

timer, measuring "chilling" during egg diapause in Bombyx mori.

Blake (1959) reported evidence of a circannual rhythm for larval diapause in a British population of the varied carpet beetle Anthrenus verbasci. Recently, Nisimura \& Numata (2001) described a circannual phase response curve for the circannual pupation rhythm in a Japanese population of $A$. verbasci. The authors propose that a decrease in the photophase acts as an "autumn signal" causing a phase advance in subjective summer and a phase delay in subjective winter. Endogenous rhythm, alternating diapause and reproduction, was recorded in the ants Formica aquilonia and $F$. polyctena (Kipyatkov \& Shenderova, 1990). While the chronobiological achievements in the field of circadian clocks are impressive, the problem of measuring the passing of time during diapause development has been neglected.

\section{ROLE OF TEMPERATURE IN DIAPAUSE DEVELOPMENT}

The function of temperature in diapause development has been a source of controversy and misunderstanding since the term and concept were coined by Andrewartha (1952). However, he cannot be blamed for later oversimplification and wrong generalisation of his paradigm. The pages dealing with the influence of temperature on diapause development (Andrewartha, 1952, pp. 56-59) demonstrate that the author was extremely cautious in explaining his concept. He wrote, e.g., : "For h e a 1 th y completion of diapause the larvae (of Cydia pomonella) require to be held for several months at low temperatures." or "The association of low temperature with the disappearance of diapause is widespread but $n$ o $t$ $\mathrm{qu}$ i te ge ne r a 1 " and he gives the range $5-13^{\circ} \mathrm{C}$ as an example of low temperatures. In spite of such clear limitations given by Andrewartha (1952) and a precise explanation soon afterwards by Lees (1955) many researchers concentrated their investigations on the sim-

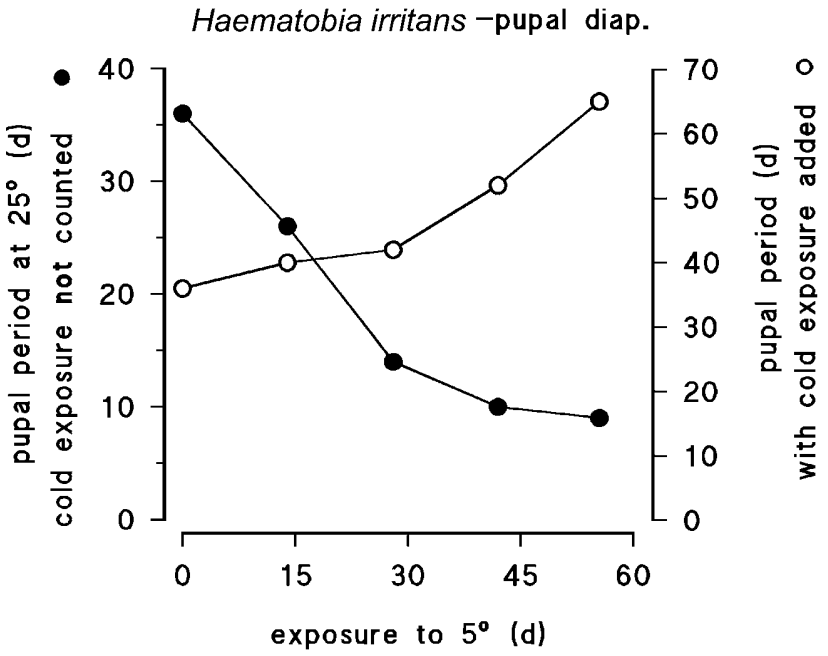

Fig. 7. The effect of cold exposure at $5^{\circ} \mathrm{C}$ (compared to the exposure at constant $25^{\circ} \mathrm{C}$ ) on pupal diapause (pharate adult) in Haematobia irritans with and without the "chilling" period (data from Lysyk, 1999).

plified assessment of whether the resumption of morphogenesis was possible without "chilling" (often even a control experiment was omitted) while the $\mathrm{qu}$ a $1 \mathrm{i} \mathrm{t} \mathrm{y}$ of diapause development was neglected. Although the topic was clarified later in several compendia and review articles (Tauber \& Tauber, 1976; Hodek, 1983; Denlinger, 1985; Tauber et al., 1986; Danks, 1987; Hodek \& Hodkova, 1988), studies with such simplified aims are still being published and the overgeneralisation survives that "chilling" is a prerequisite for diapause development in a 11 insects. It seems to be true in some cases (Table 2), while high temperatures enable completion of winter diapause in many other insects (Table 3); for earlier examples see also Hodek \& Hodkova (1988).

In spite of the previous explanations by several authors, it has to be stressed again that ranges of temperatures effective for morphogenesis and for diapause development may overlap to different degrees. Thus using only one cool temperature is not an adequate approach to study the effects of temperature on diapause development. Rare was the use of a broad range of temperatures, as in the detailed studies on eggs of Austroicetes cruciata (Andrewartha, 1952), eggs of Atrachya menetriesi (Ando, 1983) and larvae of Lagria hirta (Zhou \& Topp, 2000). The thermal optima are different for different processes; thus the optimum temperature is different for the incidence of diapause completion, rate/duration of diapause development or fitness of post-diapause individuals (which can be measured as longevity or reproductive ability). Lees (1955, p. 53) preferred duration over proportion as an "index of the completion of diapause development" and he did not mention fitness. His opinion probably affected many experiments. It appears, however, that all criteria yield important information for rating the value of temperature for diapause development. All these three parameters were monitored during diapause development in adults of the heteropteran Pyrrhocoris apterus (Hodek, 
TABLE 3. Species in which cool temperatures are not a prerequisite for completion of diapause development under diapause promoting photoperiod; winter diapause; papers listed in Hodek \& Hodkova, 1988, which include 33 additional species, are not repeated here).

\begin{tabular}{|c|c|}
\hline \multicolumn{2}{|l|}{ Egg diapause } \\
\hline Teleogryllus commodus & Masaki et al., 1979 \\
\hline Chortoicetes terminifera & Hunter \& Gregg, 1984 \\
\hline $\begin{array}{l}\text { Diabrotica barberi } \\
\left(15 \text { or } 18^{\circ} \text { better than } 0 \text { or } 3^{\circ}\right)\end{array}$ & Fisher et al., 1994 \\
\hline Caledia captiva & Groeters, 1994 \\
\hline \multicolumn{2}{|l|}{ Larval diapause } \\
\hline Aphelinus varipes & $\mathrm{Yu}, 1992$ \\
\hline Curculio elephas & Menu, 1993 \\
\hline Zygaena trifolii $(50 \%)$ & Wipking, 1995 \\
\hline Choristoneura fumiferana & Han \& Bauce, 1996 \\
\hline Argas reflexus (Di not sure) & Dautel \& Knulle, 1998 \\
\hline Sesamia nonagrioides & Fantinou et al., 1998 \\
\hline Chlorops oryzae & Takeda \& Nagata, 1998 \\
\hline Epilachna admirabilis & Takeuchi et al., 1999 \\
\hline Coleophora alticollela & Butterfield et al., 1999 \\
\hline Diprion similis & Melcher \& Townsend, 1999 \\
\hline \multicolumn{2}{|l|}{ Pupal diapause } \\
\hline Haematobia irritans & Lysyk, 1992, 1999 \\
\hline Agrius convolvuli & Shimoda \& Kiuchi, 1997 \\
\hline Pieris melete* & Xue et al., 1997 \\
\hline Delia antiqua & Nomura \& Ishikawa, 2000 \\
\hline \multicolumn{2}{|l|}{ Adult diapause } \\
\hline Phytoseiid mites (4 spp.) & Veerman, 1992 \\
\hline Plautia stali* & Kotaki, 1998 \\
\hline Podisus maculiventris (partim) & Chloridis et al., 1997 \\
\hline Musca autumnalis & Krafsur \& Moon, 1997 \\
\hline Bombus terrestris (queens) & Beekman et al., 1998 \\
\hline
\end{tabular}

*low latitudes

1978, Fig. 8) and it was shown that temperatures suitable by some criteria were inadequate for allowing high postdiapause fecundity. In larvae of Sesamia nonagrioides the prepupal delay was slightly shortened by 16 -day exposure to $5{ }^{\circ} \mathrm{C}$, but mortality increased to $75 \%$ in comparison with only $8 \%$ at $25^{\circ} \mathrm{C}$ (Fantinou et al., 1998).

"Chilling" is part of diapause development. When the duration of diapause is used as a criterion, quite often the results on the effects of temperature on diapause development are misinterpreted because the duration of storage at low temperatures is not counted as part of diapause development. When this period is added, no or only a very smal shortening of diapause development can be recorded. Earlier examples (the tortricid Choristoneura viridis - Schmidt, 1977 and the tenthredinid Pikonema alaskensis - Bartelt et al., 1981) were noted by Hodek \& Hodkova (1988, pp. 154, 156). A similar misinterpretation is found in a study on larval diapause of the braconid parasitoid, Cotesia glomerata (Ishii et al., 2000). The pre-
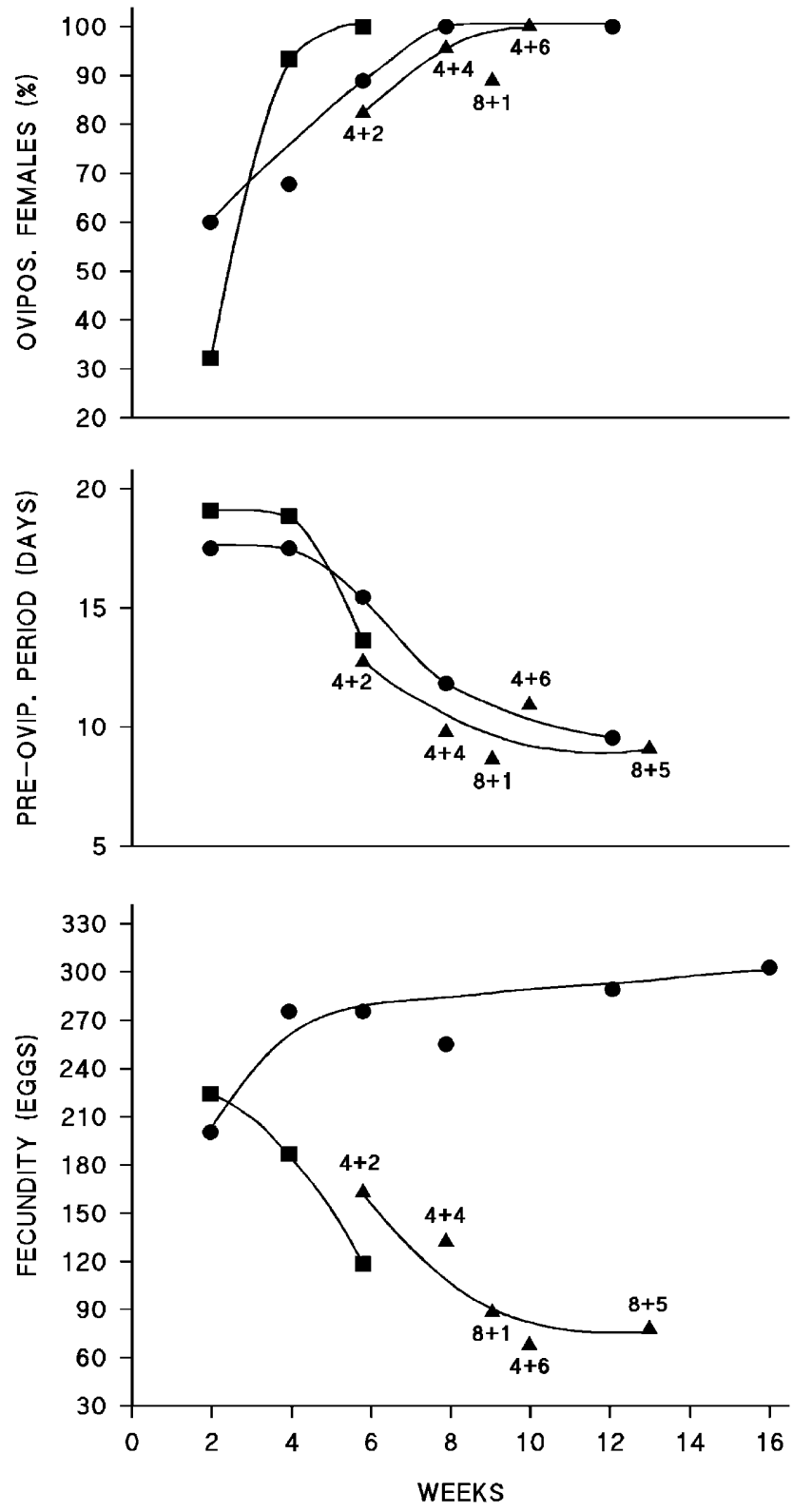

Fig. 8. The effect of outdoor conditions (๑) and laboratory exposure at $5(\boldsymbol{\square})$ or $16+5^{\circ} \mathrm{C}(\boldsymbol{\Delta})$ on reproductive parameters in Pyrrhocoris apterus females (recorded after transfer to $25^{\circ} \mathrm{C}$ and 12L : 12D; from Hodek, 1978).

pupal period had not, in fact, "decreased with elongation of $4^{\circ}$ exposure"; on the contrary, the duration of the prepupal period increases, when the time spent at $4^{\circ} \mathrm{C}$ is added (Fig. 6). The time spent at $4^{\circ} \mathrm{C}$ cannot be disregarded, because the authors report that in this insect "the diapause development can be completed at a temperature of e.g. $4^{\circ} \mathrm{C}$ ".

In the pharate adult of the horn fly, Haematobia irritans (Fig. 7), a treatment by $5^{\circ} \mathrm{C}$ elicits diapause development only slightly less rapidly than exposure to $25^{\circ} \mathrm{C}$ (Lysyk, 1992, 1999). H. irritans has thus been added to a small group of insects in which diapause development can be completed equally well at both cool and high temperatures. Similarly, the egg diapause of Chrysolina aurichalcea lasts slightly longer when a part of diapause 
development is spent at $3^{\circ} \mathrm{C}$ then when control eggs are kept continuously at $15^{\circ} \mathrm{C}$ (Fujiyama \& Noda, 1996). (For earlier examples of double temperature optima see Hodek \& Hodkova, 1988.)

Temperature exposure vs. increase. Another source of controversy is the inevitable large increase in experimental temperature when animals are exposed to low temperatures and then incubated at high temperatures, most often $25^{\circ} \mathrm{C}$. If the low temperature is $5^{\circ}$ or $10^{\circ} \mathrm{C}$, the subsequent increase is abrupt, by $15^{\circ}$ or $20^{\circ}$. Such an increase might represent a strong activating stimulus for the tachytely. It is difficult to distinguish the effect of the temperature during exposure from the effect of the increase (Hodek, 1978; Danks, 1987). In the sense of his concept of "steplike reactivation", Zaslavski (1988) denied the effect of cold exposure itself as he considered it to provide only a contrast to the subsequent incubation temperature. In his last paper, he assumed that the processes at low and high temperatures are integrated in such a way that the cumulative effect of low and then high temperatures is higher than the effect of warm conditions alone (Zaslavski, 1995, p. 411).

Role of cool temperatures. Many species require cool temperatures for successful completion of diapause development (Table 2). But even when diapause can be completed relatively quickly and at high incidence without chilling, cool temperatures lead to synchronous resumption of post-diapause morphogenesis and help to maintain the $\mathrm{v}$ i a b i 1 i t y of post-diapause insects. The condition of post-diapause adults is indicated by their reproduction and longevity (Fig. 8). It is perhaps the most serious drawback of studies on diapause development that the condition of post-diapause insects, stressed by Andrewartha (1952) by his words: "h e a $1 \mathrm{t} \mathrm{h}$ y completion of diapause", has been greatly neglected.

\section{CONCLUSIONS}

Every individual can follow several (at least two) possible developmental pathways that are evidently interlinked and mutually complementary. Thus the time of diapause passed at any condition, including exposure to very low temperatures, has to be considered. Some authors were able to record two thermal optima for diapause development. In temperature studies the experimental range ought to be adequately wide and less affected then in the past by a priori assumptions. Stimulation by temperature increase or improvement in food or other conditions has to be considered.

The success of diapause completion can be estimated by at least four parameters; none of them can be dismissed. (1) The easily visible consequence of diapause completion, such as incidence of developmental steps, often is the only parameter measured. (2) The rate of diapause development, i.e., the delay or duration is frequently recorded. (3) The effect on synchronization of life-history events has been much less often considered. (4) In spite of its importance, the vigour of post-diapause insects (indicated by long-term survival or fecundity) has usually been neglected.
ACKNOWLEDGEMENTS. It has been a great honour to read a lecture at a symposium organised to celebrate the anniversary of professor A.S. Danilevski, a great man who has meant so much for the progress of the ecophysiological study of diapause. There is also a 50 years anniversary of the publication of the pivotal paper on diapause development by professor H.G.Andrewartha.

\section{REFERENCES}

ANDO Y. 1983: Diapause and geographic variation in a leaf beetle. In: Brown V.K. \& Hodek I. (eds) Diapause and Life Cycle Strategies in Insects. Junk, The Hague, pp. 127-141.

ANDREWARTHA H.G. 1952: Diapause in relation to the ecology of insects. Biol. Rev. 27: 50-107.

BAKER F.C. 1935: The effect of photoperiod on resting, treehole, mosquito larvae. Can. Entomol. 67: 149-153.

Bartelt R.J., Kulman H.M. \& Jones R.L. 1981: Effects of temperature on diapausing cocoons of the yellowheaded spruce sawfly, Pikonema alaskensis. Ann. Entomol. Soc. Am. 74: 472-477.

Beekman M., van Stratum P. \& Lingeman R. 1998: Diapause survival and post-diapause performance in bumblebee queens (Bombus terrestris). Entomol. Exp. Appl. 89: 207-214.

BLAKE G.M. 1959: Control of diapause by an "internal clock" in Anthrenus verbasci (Col.: Dermestidae). Nature 183: 126-127.

BRowNING T.O. 1952a: The influence of temperature on the completion of diapause in the eggs of Gryllulus commodus. Aust. J. Sci. Res., Biol. Sci. 5: 112-127.

BRowning T.O. 1952b: On the rate of completion of diapause development at constant temperatures in the eggs of Gryllulus commodus. Aust. J. Sci. Res., Biol. Sci. 5: 344-353.

Butterfield J., Telfer G., Fielding C. \& Coulson J.C. 1999: The diapause syndrom in the seed-eating caterpillar of Coleophora alticolella. Entomol. Exp. Appl. 92: 321-330.

Chloridis A.S., Koveos D.S. \& Stamopoulos D.C. 1997: Effect of photoperiod on the induction and maintenance of diapause and on development of the predatory bug Podisus maculiventris (Hem.: Pentatomidae). Entomophaga 42: 427-434.

Collier R.H., Elliott M.S. \& Finch S. 1994: Development of the overwintering stages of the carrot fly, Psila rosae (Diptera: Psilidae). Bull. Entomol. Res. 84: 469-476.

Danilevski A.S. 1961: Photoperiodism and Seasonal Development of Insects. Leningrad Univ. Press, Leningrad, 243 pp. [in Russian]

Danilevski A.S. \& Sheldeshova G.G. 1968: The adaptive significance of the photoperiodic and cold reactivation. In: Danilevski A.S. (ed.) Photoperiodic Adaptations in Insects and Acari. Leningrad Univ. Press., Leningrad, pp. 80-99. [in Russian]

DANKS H.V. 1987: Insect Dormancy: an Ecological Perspective. Biol. Survey Canada, Natl. Mus. Nat. Sci., Ottawa, 439 pp.

Dautel H. \& Knulle W. 1998: The influence of physiological age of Argas reflexus larvae (Acari: Argasidae) and of temperature and photoperiod on induction and duration of diapause. Oecologia 113: 46-52.

DenLinger D.L. 1985: Hormonal control of diapause. In: Kerkut G.A. \& Gilbert L.I. (eds): Comprehensive Insect Physiology Biochemistry and Pharmacology, Vol. 8. Pergamon, Oxford, pp. 353-412.

Du Merte P. 1999: Egg development and diapause: ecophysiological and genetic basis of phenological polymorphism and adaptation to varied hosts in the green oak tortrix, Tortrix viridana L. (Lepidoptera: Tortricidae). J. Insect Physiol. 45: 599-611. 
Fantinou A.A., Tsitsipis J.A. \& Karandinos M.G. 1998: Diapause termination in Sesamia nonagrioides (Lepidoptera: Noctuidae) under laboratory and field conditions. Environ. Entomol. 27: 53-58.

FISHER J.R. 1997: Embryonic diapause in Aulocara elliotti and Ageneotettix deorum (Orthoptera: Acrididae): lowtemperature relationships. Environ. Entomol. 26: 906-911.

Fisher J.R., JACKSON J.J. \& LeW A.C. 1994: Temperature and diapause development in the egg of Diabrotica barberi (Coleoptera: Chrysomelidae). Environ. Entomol. 23: 464-471.

Fisher J.R., Kemp W.P. \& Pierson F.B. 1996: Aulacora elliotti (Orthoptera: Acrididae): diapause termination, postdiapause development, and prediction of hatch. Environ. Entomol. 25: $1158-1166$.

FootitT S. \& CoHn M.A. 2001: Developmental arrest: from sea urchins to seeds. Seed Sci. Res. 11: 3-16.

FumYama S. \& NoDA T. 1996: On difference of intensity of egg diapause in Chrysolina aurichalcea (Mannerheim) populations from different altitudes of the Utsukushigahara heights, central Honshu, Japan. New Entomol. 45: 34-38

Gadenne Ch., Dufour M.-C., Rossignol F., Becard J.-M. \& Courllaud F. 1997: Occurrence of non-stationary larval moults during diapause in the corn-stalk borer, Sesamia nonagrioides (Lepidoptera: Noctuidae). J. Insect Physiol. 43: 425-431.

GeHRKEn U. 1985: Physiology of diapause in the adult bark beetle, Ips acuminatus Gyll., studied in relation to cold hardiness. J. Insect Physiol. 31: 909-916.

Gerson E.A., Kelsey R.G. \& Ross D.W. 1999: Pupal diapause of Coloradia pandora (Lepidoptera: Saturniidae). Pan-Pac. Entomol. 75: 170-177.

Gillot C. 1995: Entomology. 2nd ed. Plenum, New York, London, $798 \mathrm{pp}$.

Gray D.R., Ravlin F.W., Regniere J. \& Logan J.A. 1995: Further advances toward a model of gypsy moth (Lymantria dispar) egg phenology: respiration rates and thermal responsiveness during diapause, and age-dependent developmental rates in postdiapause. J. Insect Physiol. 41: 247-256

Groeters F.G. 1994: The adaptive role of facultative embryonic diapause in the grasshopper Caledia captiva (Orthoptera: Acrididae) in southeastern Australia. Ecography 17: 221-228.

Han E.-N. \& Bauce E. 1996: Diapause development of spruce budworm larvae, Choristoneura fumiferana (Clem.) (Lepidoptera: Tortricidae) at temperatures favouring post-diapause development. Can. Entomol. 128: 167-169.

HARADA T. \& TANIGUCHI Y. 2001: Adult diapause of a monovoltine water strider Gerris gracilicornis (Heteroptera: Gerromorpha). Acta Soc. Zool. Bohem. 65: 181-187.

Henderson I.F., Henderson W.D. \& Kenneth J.H. 1953: A Dictionary of Scientific Terms. 5th ed., Van Nostrand, New York, $506 \mathrm{pp}$.

Hodek I. 1978: Role of temperature in diapause of Pyrrhocoris apterus (Heteroptera). Vest. Cs. Spol. Zool. 42: 172-187.

HoDeK I. 1981: Le role des signaux de l'environnement et des processus endogenes dans la regulation de la reproduction par la diapause imaginale. Bull. Soc. Zool. France 106: 317-325.

HoDeK I. 1983: Role of environmental factors and endogenous mechanisms in the seasonality of reproduction in insects diapausing as adults. In: Brown V.K. \& Hodek I. (eds) Diapause and Life Cycle Strategies in Insects. Junk, The Hague, pp. 9-33.

HoDEK I. 1996: Diapause development, diapause termination and the end of diapause. Eur. J. Entomol. 93: 475-487.

HODEK I. 1999: Environmental regulation and some neglected aspects of insect diapause. Entomol. Sci. 2: 533-537.
Hodek I. \& Hodkova M. 1988: Multiple role of temperature during insect diapause: a review. Entomol. Exp. Appl. 49: 153-165.

Hodkova M. 1999: Regulation of diapause and reproduction in Pyrrhocoris apterus (Heteroptera) - neuroendocrine outputs (mini-review). Entomol. Sci. 2: 563-566.

HoDkova M. \& HoDEK I. 1989: Role of feeding, photoperiod and temperature in the regulation of reproduction by the neuroendocrine system in Pyrrhocoris apterus. In: Regulation of Insect Reproduction IV. Tonner M., Soldan T. \& Bennetova B. (eds), Academia, Praha, pp. 377-384.

Hogan T.W. 1960: The onset and duration of diapause in eggs of Acheta commodus (Orthoptera). Aust. J. Biol. Sci. 13: $14-29$.

Holters W. 1981: Untersuchungen zur Steuerung des Kurztagund Langtag-Prozesses der Gonadenreifung bei Pterostichus angustatus (Col: Carabidae). Zool. Jb. Physiol. 85: 426-461.

Horton D.R., Broers D.A., Hinojosa T. \& Lewis T.M. 1998: Ovarian development in overwintering pear psylla, Cacopsylla pyricola (Homoptera: Psyllidae): seasonality and effects of photoperiod. Can. Entomol. 130: 859-867.

Hunter D.M. \& Gregg P.C. 1984: Variation in diapause potential and strength in eggs of the Australian plague locust, Chortoicetes terminifera (Orthoptera: Acrididae). J. Insect Physiol. 30: $867-870$.

Inoue T. 1994: Adult diapause of the fleabeetle, Argopistes biplagiatus. III. Effects of low temperatures on termination of winter diapause. Appl. Entomol. Zool. 29: 433-436.

IRWIN J.T., BenNetT V.A. \& LeE Jr. R.E. 2001: Diapause development in frozen larvae of the goldenrod gall fly, Eurosta solidaginis (Diptera: Tephritidae). J. Comp. Physiol. B 171: 181-188.

IsHiHARA M. \& SHImADa M. 1995: Trade-off in allocation of metabolic reserves: effect of diapause on egg production and adult longevity in a multivoltine bruchid, Kytorhinus sharpianus. Funct. Ecol. 9: 618-624.

IshinARA M. \& SHIMAdA M. 1996: Bi- and trivoltine complex life cycles in a Kanto (Japan) population of a wild bruchid Kytorhinus sharpianus. Entomol. Exp. Appl. 79: 247-253.

Ishil M., Sato Y. \& Tagawa J. 2000: Diapause in the braconid wasp, Cotesia glomerata (L.). II. Factors inducing and terminating diapause. Entomol. Sci. 3: 201-206.

IsHIKAWA Y., Yamashita T. \& NomuRA M. 2000: Characteristics of summer diapause in the onion maggot, Delia antiqua (Diptera: Anthomyiidae). J. Insect Physiol. 46: 161-167.

Kai H., Kotani Y., Miao Y. \& AZuma M. 1995: Time interval measuring enzyme for resumption of embryonic development in the silkworm, Bombyx mori. J. Insect Physiol. 41: 905-910.

Kai H., Arai T. \& Yasuda F. 1999: Accomplishment of timeinterval activation of esterase A4 by simple removal of PIN fraction. Chronobiol. Intern. 16: 51-58.

Kalushiov P., Hodkova M., Nedved O. \& Hodek I. 2001: Effect of thermoperiod on diapause intensity in Pyrrhocoris apterus (Heteroptera Pyrrhocoridae). J. Insect Physiol. 47: $55-61$.

KipyatKov V.E. \& Shenderova S.S. 1990: The endogenous rhythm of queens reproductive activity in red wood ants (Formica rufa group). Zool. Zh. 69: 40-52. [in Russian]

Kostal V., Shimada K. \& Hayakawa Y. 2000: Induction and development of winter larval diapause in a drosophilid fly, Chymomyza costata. J. Insect Physiol. 46: 417-428.

KотAKI T. 1998: Effects of low temperature on diapause termination and body colour change in adults of a stink bug, Plautia stali. Physiol. Entomol. 23: 53-61. 
KRAFSUR E.S. \& MoOn R.D. 1997: Bionomics of the face fly, Musca autumnalis. Anmu. Rev. Entomol. 42: 503-523.

LAING J.E. \& CoRRIGAN J.E. 1995: Diapause induction and postdiapause emergence in Trichogramma minutum Riley (Hymenoptera: Trichogrammatidae): the role of host species, temperature, and photoperiod. Can. Entomol. 127: 103-110.

LeEs A.D. 1955: The Physiology of Diapause in Arthropods. Cambridge Univ. Press, $151 \mathrm{pp}$.

LeINAAS H.P. \& BLEKEN E. 1983: Egg diapause and demographic strategy in Lepidocyrtus lignorum (Collembola: Entomobryidae). Oecologia 58: 194-199.

Lopez C., ElzaguirRe M. \& Albajes R. 1995: Diapause detection and monitoring in the Mediterranean corn stalk borer. Physiol. Entomol. 20: 330-336.

Lushai G., Hardie J. \& Harrington R. 1996: Diapause termination and egg hatch in the bird cherry aphid, Rhopalosiphum padi. Entomol. Exp. Appl. 81: 113-115.

LYSYK T.J. 1992: Effect of larval rearing temperature and maternal photoperiod on diapause in the horn fly (Diptera: Muscidae). Environ. Entomol. 21: 1134-1138.

LYsYK T.J. 1999: Effect of temperature on time to eclosion and spring emergence of postdiapausing horn flies (Diptera: Muscidae). Environ. Entomol. 28: 387-397.

Mansingh A. 1971: Physiological classification of dormancies in insects. Can. Entomol. 103: 983-1009.

MASAKI S. 1960: Thermal relations of diapause in the eggs of certain crickets (Orthoptera: Gryllidae). Bull. Fac. Agric. Hirosaki Univ. 6: 5-20.

Masaki S., Ando Y. \& Watanabe A. 1979: High temperature and diapause termination in the eggs of Teleogryllus commodus (Orth.: Gryllid.). Kontyu 47: 493-504.

Melcher H.L. \& Townsend L.H. 1999: Diapause induction in a Kentucky population of Diprion similis (Hymenoptera: Diprionidae). J. Entomol. Sci. 34: 328-334.

Menu F. 1993: Diapause development in the chestnut weevil Curculio elephas. Entomol. Exp. Appl. 69: 91-96.

Miles J.E., Bale J.S. \& Hodkinson I.D. 1998: Life cycle regulation in the heather psyllid Strophingia ericae: responses to temperature and photoperiod. Physiol. Entomol. 23: 376-381.

Mironas P.G. \& Savopoulou-Sultani M. 2000: Diapause induction and termination in the parasitoid Colpoclypeus florus (Hymenoptera: Eulophidae): role of photoperiod and temperature. Ann. Entomol. Soc. Am. 93: 512-518.

Mochizuki M. \& TAKafun A. 1996: Effect of photoperiod and temperature on the diapause termination of the Kanzawa spider mite, Tetranychus kanzawai Kishida (Acari: Tetranychidae). J. Acarol. Soc. Jpn. 5: 83-88.

NAKAO S. 1998: Effects of photoperiod and temperature on induction and termination of reproductive diapause of Thrips setosus (Thysanoptera: Thripidae). Jpn. J. Appl. Entomol. Zool. 42: 172-173.

NaKamura K. \& Numata H. 1997: Effects of environmental factors on diapause development and postdiapause oviposition in a phytophagous insect, Dybowskyia reticulata. Zool. Sci. 14: 1019-1024.

NisimuRA T. \& Numata H. 2001: Endogenous timing mechanism controlling the circannual pupation rhythm of the varied carpet beetle Anthrenus verbasci. J. Comp. Physiol. A 187: $433-440$.

Nomura M. \& Ishrikawa Y. 2000: Biphasic effect of low temperature on completion of winter diapause in the onion maggot, Delia antiqua. J. Insect Physiol. 46: 373-377.

Pires C.S.S., Sumi E.R., Fontes E.M.G., Tauber C.A. \& Tauber M.J. 2000: Dry-season embryonic dormancy in Deois fla- vopicta (Homoptera: Cercopidae): roles of temperature and moisture in nature. Environ. Entomol. 29: 714-720.

Precht H. 1963: Versuche mit der Schmalwanze Ischnodemus sabuleti. Ein Beitrag zum Diapauseproblem. Zool. Anz. 171: 13-28.

Precht H. 1964: Gibt es biologische "Langzeituhren" bei wechselwarmen Tieren ? Einige Versuche zum Problem der Beendigung von Diapausen bei Insekten. Zool. Anz. 172: $87-95$.

REGNIERE J. 1990: Diapause termination and changes in thermal responses during postdiapause development in larvae of the spruce budworm, Choristoneura fumiferana. J. Insect Physiol. 36: $727-735$.

ReISEN W.K., SMIth P.T. \& Lothrop H.D. 1995: Short-term reproductive diapause by Culex tarsalis (Diptera: Culicidae) in the Coachella Valley of California. J. Med. Entomol. 32: 654-662.

Rinehart J.P., Cikra-Ireland R.A., Flannagan R.D. \& DenLINGER D.L. 2001: Expression of ecdysone receptor is unaffected by pupal diapause in the flesh fly, Sarcophaga crassipalpis, while its dimerization partner, USP, is downregulated. J. Insect Physiol. 47: 915-921.

Schмпт F.H. 1977: Differences in thermal requirements for diapause termination in two western Choristoneura spp. (Lepidoptera: Tortricidae). Can. Entomol. 109: 1469-1474.

Schooneveld H., SANchez A.O. \& DE WiLde J. 1977: Juvenile hormone induced break and termination of diapause in the Colorado potato beetle. J. Insect Physiol. 23: 689-696.

SHIMOdA M. \& KIUCHI M. 1997: Effect of chilling of diapause pupa on adult emergence in the sweet potato hornworm, Agrius convolvuli (Linne) (Lepidoptera: Sphingidae). Appl. Entomol. Zool. 32: 617-624.

SHINTANI Y. \& IshrKaWA Y. 1997a: Diapause avoidance induced by low temperature in the yellow-spotted longicorn beetle, Psacothea hilaris. Entomol. Exp. Appl. 85: 11-15.

SHINTANI Y. \& IsHrKawA Y. 1997b: Effects of photoperiod and low temperature on diapause termination in the yellowspotted longicorn beetle (Psacothea hilaris). Physiol. Entomol. 22: $170-174$.

Simpson G.G. 1944: Tempo and Mode in Evolution. Columbia Univ. Press, New York.

Simpson G.G. 1953: The Major Features of Evolution. Columbia Univ. Press, New York, 434 pp.

Tadini-Vitagliano G., Valentino F. \& Migliore L. 1982: Is the mechanism present in Asellus aquaticus an evolutionary stage towards an endogenous calendar? Z. Zool. Syst. Evol. Forsch. 20: $144-155$.

TAKEDA M. \& NAGATA T. 1998: Effects of temperature and winter diapause on survival and development in bivoltine and trivoltine ecotypes of the rice stem maggot, Chlorops oryzae (Diptera: Chloropidae), reared on winter host. Appl. Entomol. Zool. 33: 85-96.

Takeuchi M., Shmizu A., Ismmara A. \& Tamura M. 1999: Larval diapause induction and termination in a phytophagous lady beetle, Epilachna admirabilis (Coleoptera: Coccinellidae). Appl. Entomol. Zool. 34: 475-479.

TANAKA H. 1994: Embryonic diapause and life cycle in the migratory locust, Locusta migratoria L. (Orthoptera: Acrididae), in Kyoto. Appl. Entomol. Zool. 29: 179-191.

TAUber M.J. \& TAUber C.A. 1976: Insect seasonality: diapause maintenance, termination, and post-diapause development. Annu. Rev. Entomol. 21: 81-107.

Tauber M.J., Tauber C.A. \& Masaki S. 1986: Seasonal Adaptations of Insects. Oxford Univ. Press, New York, Oxford, 411 pp. 
Tischlen W. 1963: Weitere Untersuchungen zur Oekologie der Schmalwanze Ischnodemus sabuleti (Hem.: Lygaeidae). Zool. Anz. 171: 339-349.

TOGASHI K. 1995: Interacting effects of temperature and photoperiod on diapause in larvae of Monochamus alternatus (Coleoptera: Cerambycidae). Jpn. J. Entomol. 63: 243-252.

Topp W. 1984: Synchronisation und polymorphe Termination der Diapause bei Oxytelus rugosus (Col.: Staphylinidae). Zool. Jb. Syst. 106: 1-49.

Topp W. 1994: Seasonal time partitioning and polymorphism in the developmental cycles of sympatric Staphylinoidea (Coleoptera) living in an unstable environment. In: Danks H.V. (ed.) Insect Life-Cycle Polymorphism. Kluwer, Dordrecht, Boston, London, pp. 277-312.

Tzanakakis M.E., VeEnendaAl R.L. \& VeErman A. 1992: Effects of photoperiod and temperature on the termination of diapause in the univoltine seedwasp Eurytoma plotnikovi. Physiol. Entomol. 17: 176-182.

TzanaKaKis M.E. \& VeERMAN A. 1994: Effect of temperature on the termination of diapause in the univoltine almond seed wasp Eurytoma amygdali. Entomol. Exp. Appl. 70: 27-39.

VeERman A. 1992: Diapause in phytoseiid mites: a review. Exp. Appl. Acarol. 14: 1-60.

Vinogradova E.B. 1991: Diapause and its Control in Flies. Nauka Publ. House, St.Petersburg, 255 pp. [in Russian]

VinOGRADOVA E.B. \& BogdANOVA T.P. 1984: Relation between larval and adult diapause in the ontogeny of Calliphora vicina. Dokl. Acad. Nauk SSSR 278: 505-507. [in Russian]

Watanabe M. \& TanaKa K. 1998: Adult diapause and cold hardiness in Aulacophora nigripennis (Coleoptera: Chrysomelidae). J. Insect Physiol. 44: 1103-1110.
Watson N.H.P. \& SMallman B.N. 1971: The physiology of diapause in Diacyclops navus (Crustacea, Copepoda). Can. J. Zool. 49: 1449-1454.

WIPKING W. 1995: Influences of daylength and temperature on the period of diapause and its ending process in dormant larvae of burnet moths (Lepidoptera: Zygaenidae). Oecologia 102: $202-210$.

Wilson G.R. \& LARSEN J.R. 1974: Debraining and diapause development in Manduca sexta pupae. J. Insect Physiol. 20: 2459-2473.

Xue F.-S., Kallenborn H.G. \& Wei H.-Y. 1997: Summer and winter diapause in pupae of the cabbage butterfly, Pieris melete Menetries. J. Insect Physiol. 43: 701-707.

YAMANAKA M. \& FumYama S. 1994: The larvae of Allomyrina dichotoma enter diapause. New Entomol. 43: 60-64.

Yatsuda T., Narahara M., TanaKa S. \& Wakamura S. 1994: Thermal responses in the citrus fruit fly, Dacus tsuneonis: evidence for a pupal diapuse. Entomol. Exp. Appl. 71: 257-261.

Yu D.S. 1992: Effects of photoperiod and temperature on diapause of two Aphelinus spp. (Hymenoptera: Aphelinidae) parasitizing the Russian wheat aphid. Can. Entomol. 124: 853-860.

ZASLAVSKI V.A. 1988: Insect Development - Photoperiodic and Temperature Control. Springer, Berlin, $187 \mathrm{pp}$.

ZASLAVSKI V.A. 1995: Induction and deinduction in insect photoperiodism: experimental evidence and a model. Eur. J. Entomol. 92: 401-413.

Zhou H.Z. \& Topp W. 2000: Diapause and polyphenism of lifehistory of Lagria hirta. Entomol. Exp. Appl. 94: 201-210.

Received November 19, 2001, revised April 17, 2002; accepted April 17, 2002 